\title{
PERBANDINGAN METODE SAW DAN TOPSIS PADA KASUS UMKM
}

\author{
Muh. Aliyazid Mude \\ ali.mude@yahoo.com \\ Teknik Informatika Universitas Muslim Indonesia
}

\begin{abstract}
Abstrak
Dalam pengambilan keputusan terhadap masalah berdasarkan sebuah analisa pribadi yang subjektif tanpa menggunakan metode tertentu, biasanya memiliki tingkat kesalahan yang tinggi sehingga hal ini akan membahayakan pengambilan keputusan yang berujung pada penyesalan. Ada banyak metode Decision Support System (DSS) yang dapat digunakan untuk proses pengambilan keputusan, namun 2 metode yang sering digunakan untuk melakukan proses pengambilan keputusan yakni metode Simple Additive Weighting (SAW) dan Technique For Others Referencean by Similarity to Ideal Solution (TOPSIS). Karena itu untuk mengetahui yang terbaik dari 2 metode tersebut, maka dilakukan perubahan pembobotan dan hasil pengujian diperoleh kesamaan dalam proses pengembilan keputusan (pemecahan masalah). Sehingga dalam pengambilan keputusan dapat menggunakan salah satu metode SAW atau TOPSIS. Perangkingan 2 metode tersebut akan menentukan lokasi yang strategis untuk meningkatkan omzet usaha percetakan (UMKM).
\end{abstract}

Kata Kunci: DSS, SAW, TOPSIS, UMKM

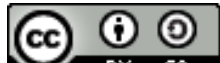

\section{ILKOM Jurnal Ilmiah work is licensed under a CCA-SA 4.0 International License.}

\section{Pendahuluan}

Dalam mengambil keputusan terhadap suatu masalah haruslah tepat sasaran, karena hal ini berkaitan dengan tindakan yang akan dilakukan. Apalagi masalah tersebut terkait dengan kemajuan suatu organisasi atau perusahaan yang melibatkan banyak pihak, sehingga kesalahan yang timbul berdampak pada mundurnya (gagalnya) perusahaan tersebut. Karena itu perlu suatu teknik atau metode dalam mengambil keputusan. Perusahaan yang gagal biasanya muncul dari keputusan yang lemah karena keputusan yang diambil hanya berdasarkan persepsi pimpinan tanpa melakukan sebuah kajian mendalam pada masalah yang ada. Beberapa metode yang banyak digunakan dalam pengambilan keputusan pada hal yang berkaitan dengan multiple attribute decision making (MADM) diantaranya: simple additive weighting (SAW), weighted product (WP), TOPSIS dan analytic hierarchy process (AHP), namun 2 metode yang sering digunakan yakni SAW dan TOPSIS dalam pengabilan keputusan oleh pihak manajemen. Sehingga perlu mendalami 2 metode tersebut agar diketahui metode yang lebih baik dalam pengambilan suatu keputusan. Pelaksanaan 2 metode tersebut dilakukan pada salah satu usaha percetakan (UMKM) di kota Makassar.

Adapun rumusan masalah sebagai berikut: bagaimana pemanfaatan metode SAW dan TOPSIS dalam mengatasi kasus semi terstruktur dan bagaimana mencari model yang lebih baik apakah SAW atau TOPSIS dalam pengambilan keputusan UMKM. Sehingga tujuan yang diharapkan adalah menghasilkan solusi yang tepat dengan model SAW dan TOPSIS dan mengetahui perbandingan model yang terbaik dalam menyelesaikan suatu kasus UMKM semi terstruktur

\section{Landasan Teori}

Menurut Bonczek (1980) Sistem pendukung keputusan merupakan suatu sistem komputer yang berisi 3 komponen interaksi, yaitu: sistem bahasa (mekanisme komunikasi antara pengguna dengan komponen lain dalam DSS), sistem pengetahuan (gudang pengetahuan dari domain permasalahan yang berupa data atau prosedur), dan sistem pemrosesan masalah (hubungan antara 2 komponen yang berisi 1 atau lebih kapabilitas dalam memanipulasi masalah yang dibutuhkan dalam pengambilan keputusan) [1]. Menurut Raymond McLeod, Jr. (1998) Sistem Pendukung Keputusan merupakan sebuah sistem yang menyediakan kemampuan dalam penyelesaian masalah dan komunikasi untuk permasalahan yang bersifat semi-terstruktur. [2] Menurut Little (1970) Sistem pendukung keputusan adalah sekumpulan prosedur berbasis model untuk memproses data dan memberikan pertimbangan kepada seorang manajer dalam membuat keputusan [2]. Menurut Little (1970) Sistem pendukung keputusan adalah sekumpulan prosedur berbasis model untuk memproses data dan memberikan pertimbangan kepada seorang manajer dalam membuat keputusan[2]. 


\subsection{Multi-Attribute Decision Making (MADM)}

Janko (2005) [2], memberikan batasan tentang adanya beberapa fitur umum yang akan digunakan dalam MADM, yaitu: 1) Alternatif, adalah obyek-obyek yang berbeda dan memiliki kesempatan yang sama untuk dipilih oleh pengambil keputusan. 2) Atribut, sering juga disebut sebagai karakteristik, komponen, atau kriteria keputusan. Meskipun pada kebanyakan kriteria bersifat satu level, namun tidak menutup kemungkinan adanya sub kriteria yang berhubungan dengan kriteria yang telah diberikan. 3) Konflik antar kriteria, beberapa kriteria biasanya mempunyai konflik antara satu dengan yang lainnya, misalnya kriteria keuntungan akan mengalami konflik dengan kriteria biaya. 4) Bobot keputusan, bobot keputusan menunjukkan kepentingan relatif dari setiap kriteria, $W=\left(W_{1}\right.$, $\mathrm{w}_{2}, \ldots, \mathrm{w}_{\mathrm{n}}$ ). Pada MADM akan dicari bobot kepentingan dari setiap kriteria. 5) Matriks keputusan, suatu matriks keputusan $X$ yang berukuran $m \times n$, berisi elemen-elemen $x_{i j}$, yang merepresentasikan rating dari alternatif $A_{i}(i=1,2, \ldots, m)$ terhadap kriteria $C_{j}(j=1,2, \ldots, n)$.

Masalah MADM adalah mengevaluasi $m$ alternatif $A_{i}(i=1,2, \ldots, m)$ terhadap sekumpulan atribut atau kriteria $C_{j}(j=1,2, \ldots, n)$, dimana setiap atribut saling tidak bergantung satu dengan yang lainnya. Kriteria atau atribut dapat dibagi menjadi dua kategori, yaitu: 1) Kriteria keuntungan adalah kriteria yang nilainya akan dimaksimumkan, misalnya: keuntungan, IPK (untuk kasus pemilihan mahasiswa berprestasi), dll. 2) Kriteria biaya adalah kriteria yang nilainya akan diminimumkan, misalnya: harga produk yang akan dibeli, biaya produksi, dan lainnya. Pada MADM, matriks keputusan setiap alternatif terhadap setiap atribut, $\mathrm{X}$, diberikan sebagai:

$$
X=\left[\begin{array}{cccc}
x_{11} & x_{12} & \cdots & x_{1 n} \\
x_{21} & x_{22} & \cdots & x_{2 n} \\
\vdots & \vdots & & \vdots \\
x_{m 1} & x_{m 2} & \cdots & x_{m n}
\end{array}\right]
$$

Gambar 2 menunjukkan $x_{i j}$ merupakan rating kinerja alternatif ke-i terhadap atribut ke-j. Rating kinerja $(\mathrm{X})$, dan nilai bobot $(\mathrm{W})$ merupakan nilai utama yang merepresentasikan preferensi absolut dari pengambil keputusan. Masalah MADM diakhiri dengan proses perankingan untuk mendapatkan alternatif terbaik yang diperoleh berdasarkan nilai keseluruhan preferensi yang diberikan. Umumnya akan dicari solusi ideal. Pada solusi ideal akan memaksimumkan semua kriteria keuntungan dan meminimumkan semua kriteria biaya.

\section{Metode}

Ada beberapa metode yang dapat digunakan untuk menyelesaikan masalah MADM, antara lain: a) Simple Additive Weighting (SAW), b) Weighted Product (WP), c) Technique for Order Preference by Similarity to Ideal Solution (TOPSIS), dan d) Analytic Hierarchy Process (AHP), namun SAW dan TOPSIS merupakan metode yang paling mudah dan banyak digunakan dalam suatu proses pengambilan keputusan. [3] [4][5]

\subsubsection{Metode SAW}

Metode Simple Additive Weighting (SAW) sering juga dikenal istilah metode penjumlahan terbobot. Konsep dasar metode SAW adalah mencari penjumlahan terbobot dari rating kinerja pada setiap alternatif pada semua atribut. Metode SAW membutuhkan proses normalisasi matriks keputusan $(X)$ ke suatu skala yang dapat diperbandingkan dengan semua rating alternatif yang ada. 


$$
r_{i j}= \begin{cases}\frac{x_{i j}}{\operatorname{Max}_{i}} & j i k a \mathrm{j} \text { adalah atribut keuntungan (benefit) } \\ \frac{\operatorname{Min}_{i j}}{x_{i j}} & \text { jika jadalah atribut biaya (cost) }\end{cases}
$$

$r_{i j}$ adalah rating kinerja ternormalisasi dari alternatif $A_{i}$ pada atribut $C_{j} ; i=1,2, \ldots, m$ dan $j=1,2, \ldots, n$. Nilai preferensi untuk setiap alternatif $\left(V_{i}\right)$ diberikan. Nilai $V_{i}$ yang lebih besar mengindikasikan bahwa alternatif $A_{i}$ lebih terpilih.

\subsubsection{Metode TOPSIS}

TOPSIS didasarkan pada konsep dimana alternatif terpilih yang terbaik tidak hanya memiliki jarak terpendek dari solusi ideal positif, namun juga memiliki jarak terpanjang dari solusi ideal negatif. TOPSIS banyak digunakan dengan alasan: konsepnya sederhana dan mudah dipahami; komputasinya efisien; dan memiliki kemampuan untuk mengukur kinerja relatif dari alternatif-alternatif keputusan dalam bentuk matematis yang sederhana. Adapun langkah-langkah penyelesaian masalah MADM dengan TOPSIS yakni membuat matriks keputusan yang ternormalisasi; Membuat matriks keputusan yang ternormalisasi terbobot; Menentukan matriks solusi ideal positif \& matriks solusi ideal negatif;Menentukan jarak antara nilai setiap alternatif dengan matriks solusi ideal positif \& matriks solusi ideal negatif; Menentukan nilai preferensi untuk setiap alternatif. TOPSIS membutuhkan rating kinerja setiap alternatif $A_{i}$ pada setiap kriteria $C_{j}$ yang ternormalisasi sesuai formula 3.

$$
r_{i j}=\frac{x_{i j}}{\sqrt{\sum_{i=1}^{m} x_{i j}}}
$$

$$
\begin{gathered}
y_{i j}=w_{i} r_{i j} \\
A^{+}=\left(y_{1}^{+}, y_{2}^{+}, \cdots, y_{n}^{+}\right), \\
A^{-}=\left(y_{1}^{-}, y_{2}^{-}, \cdots, y_{n}^{-}\right),
\end{gathered}
$$

Solusi ideal positif $A^{+}$dan solusi ideal negatif $A^{-}$dapat ditentukan berdasarkan rating bobot ternormalisasi ( $\left.y^{i j}\right)$ dapat dilihat pada formula 4. Untuk Jarak antara alternatif $A_{i}$ dengan solusi ideal positif yang ditunjukkan pada formula 5 .

$$
\mathrm{D}_{\mathrm{i}}^{+}=\sqrt{\sum_{\mathrm{j}=1}^{\mathrm{n}}\left(\mathrm{y}_{\mathrm{j}}^{+}-\mathrm{y}_{\mathrm{ij}}\right)^{2}} ; \quad D_{i}^{-}=\sqrt{\sum_{j=1}^{n}\left(y_{i j}-y_{j}^{-}\right)^{2}} ; \quad V_{i}=\frac{D_{i}^{-}}{D_{i}^{-}+D_{i}^{+}} ;
$$

Dan Jarak antara alternatif $A_{i}$ dengan solusi ideal negatif ditunjukkan pada formula 6 . Adapun nilai preferensi untuk setiap alternatif $\left(\mathrm{V}_{\mathrm{i}}\right)$ ditunjukkan pada formula 7 .

\section{Hasil}

Menentukan kriteria dan memberikan keterangan sifat benefit atau cost

Tabel 1 Kriteria dan Sifat Kriteria

\begin{tabular}{clc}
\hline Kode & \multicolumn{1}{c}{ Nama Kriteria } & Sifat (benefit atau cost) \\
\hline $\mathrm{C}_{1}$ & Jarak antara percetakan yang ada $(\mathrm{km})$ & Benefit \\
$\mathrm{C}_{2}$ & Taksiran jumlah pelanggan dilokasi & Benefit \\
$\mathrm{C}_{3}$ & (perorang) & Benefit \\
$\mathrm{C}_{4}$ & Sewa Tengan pusat keramaian $(\mathrm{km})$ & Cost \\
\hline
\end{tabular}


Pada Tabel 1 menunjukkan keuntungan (benefit) karena memberikan peluang besar dalam menambah omzet, sementara biaya akan keluar dengan sewa tempat

Tabel 2 Nilai Alternatif

\begin{tabular}{ccccc}
\hline \multirow{2}{*}{ Alternatif } & \multicolumn{4}{c}{ Nilai di Setiap Kriteria } \\
\cline { 2 - 5 } & $\mathrm{C}_{1}$ & $\mathrm{C}_{2}$ & $\mathrm{C}_{3}$ & $\mathrm{C}_{4}$ \\
\hline $\mathrm{A}_{1}$ & 0,35 & 300 & 0,15 & 600 \\
$\mathrm{~A}_{2}$ & 0,45 & 450 & 0,25 & 400 \\
$\mathrm{~A}_{3}$ & 0,5 & 200 & 0,2 & 550 \\
\hline
\end{tabular}

Tabel 2 menunjukkan Alternatif $\mathrm{A}_{1}=$ Tamalanrea, $\mathrm{A}_{2}=$ Antang dan $\mathrm{A}_{3}=\mathrm{BTP}$. Nilai bobot $\mathrm{W}_{1}=15$, $\mathrm{W}_{2}=35, \mathrm{~W}_{3}=25$, dan $\mathrm{W}_{4}=25$.

\subsection{Penyelesaian dengan SAW}

Pada penyelesaian metode SAW normalisasi dilakukan pada matriks $\mathrm{X}$, menjadi matriks $\mathrm{R}$. Yang diilustrasikan sesuai Tabel 3.

Tabel 3 Normalisasi X ke R

\begin{tabular}{ccccc}
\hline \multirow{2}{*}{ Alternatif } & \multicolumn{4}{c}{ Nilai di Setiap Kriteria } \\
\cline { 2 - 5 } & $\mathrm{C}_{1}$ & $\mathrm{C}_{2}$ & $\mathrm{C}_{3}$ & $\mathrm{C}_{4}$ \\
\hline $\mathrm{A}_{1}$ & 0,78 & 0,67 & 0,60 & 0,67 \\
$\mathrm{~A}_{2}$ & 1,00 & 1,00 & 1,00 & 1,00 \\
$\mathrm{~A}_{3}$ & 1,11 & 0,44 & 0,80 & 0,73 \\
\hline
\end{tabular}

Normalisasi pada Tabel 3 dilakukan dengan mencari nilai maksimal (bila benefit). Nilai maksimal tersebut dijadikan pembagi dari semua nilai pada kriteria yang sama. Begitupun bila alternatifnya adalah biaya (cost) atau nilai minimum, maka nilai tersebut menjadi pembagi pada kriteria yang sama. Sehingga nilai preferensi setiap alternatif sesuai ilustrasi Tabel 4.

Tabel 4 Nilai preferensi

\begin{tabular}{ccc}
\hline Kode & Nilai & Ranking \\
$\mathrm{V}_{1}$ & 0,667 & $\mathbf{3}$ \\
$\mathrm{V}_{2}$ & 1,000 & $\mathbf{1}$ \\
$\mathrm{V}_{3}$ & 0,704 & $\mathbf{2}$ \\
\hline
\end{tabular}

NIlai Preferensi diperoleh dari nilai pembobotan tiap kriteria dikalikan dengan nilai normalisasi tiap alternatif, dan kriteria yang sama

\subsection{Penyelesaian dengan TOPSIS}

Terlebih dahulu melakukan normalisasi terhadap matriks $\mathrm{X}$, menjadi matriks $\mathrm{R}$ yang ditunjukkan pada Tabel 5.

Tabel 5 Normlisasi nilai $\mathrm{R}$

\begin{tabular}{ccccc}
\hline \multirow{2}{*}{ Alternatif } & \multicolumn{4}{c}{ Nilai di Setiap Kriteria } \\
& $\mathbf{C}_{1}$ & $\mathbf{C}_{2}$ & $\mathbf{C}_{\mathbf{3}}$ & $\mathbf{C}_{\mathbf{4}}$ \\
\hline $\mathrm{A}_{1}$ & 0,461566331 & 0,520265982 & 0,424264069 & 0,661581416 \\
$\mathrm{~A}_{2}$ & 0,593442426 & 0,780398973 & 0,707106781 & 0,441054277 \\
$\mathrm{~A}_{2}$ & 0,659380473 & 0,346843988 & 0,565685425 & 0,606449631 \\
\hline
\end{tabular}


ILKOM Jurnal Ilmiah Volume 8 Nomor 2 (Agustus 2016)

Nilai Normalisasi pada Tabel 5 diperoleh dengan membagi tiap kriteria alternative dengan total krteria $\left(A_{n} / \sum\right.$ Total kriteria). Langkah selanjutnya adalah mencari matriks $Y$ yang dilustrasikan sesuai Tabel 6.

Tabel 6 Normalisasi nilai $Y$

\begin{tabular}{ccccc}
\hline \multirow{2}{*}{ Alternatif } & \multicolumn{4}{c}{ Nilai di Setiap Kriteria } \\
\cline { 2 - 5 } & $\mathbf{C}_{\mathbf{1}}$ & $\mathbf{C}_{\mathbf{2}}$ & $\mathbf{C}_{\mathbf{3}}$ & $\mathbf{C}_{\mathbf{4}}$ \\
\hline $\mathrm{A}_{1}$ & 9,231326628 & 15,60797945 & 14,8492424 & 9,923721236 \\
$\mathrm{~A}_{2}$ & 11,86884852 & 23,41196918 & 24,74873734 & 6,615814157 \\
$\mathrm{~A}_{2}$ & 13,18760947 & 10,40531963 & 19,79898987 & 9,096744466 \\
\hline
\end{tabular}

Nilai Normalisasi $Y$ diperoleh dengan mengalikan nilai matriks $R$ dengan bobotnya $(W)$. Selanjutnya menentukan Solusi Ideal Positif $\left(A^{+}\right)$dan Solusi Ideal Negatif $\left(A^{-}\right)$

Tabel 7 Sosial Ideal Positif dan Negatif

\begin{tabular}{cccc}
\hline \multicolumn{2}{c}{ Solusi Ideal Positif } & \multicolumn{2}{c}{ Solusi Ideal Negatif } \\
Kode & Nilai & Kode & Nilai \\
\hline $\mathrm{A}_{1}^{+}$ & 13,18761 & $\mathrm{~A}_{1}^{-}$ & 9,23133 \\
$\mathrm{~A}_{2}^{+}$ & 23,41197 & $\mathrm{~A}_{2}^{-}$ & 10,40532 \\
$A_{3}^{+}$ & 24,74874 & $A_{3}^{-}$ & 14,84924 \\
$A_{4}^{+}$ & 6,61581 & $A_{4}^{-}$ & 9,09674 \\
\hline
\end{tabular}

Tabel 7 diiperoleh dari memilih nilai max $\left(A^{+}\right)$yang tertinggi dan $\left(A^{-}\right)$merupakan nilai yang terendah dari seluruh alternatif yang ada. Langkah berikutnya adalah menentukan jarak alternatif terhadap solusi ideal positif $\left(D^{+}\right)$dan solusi ideal negatif $\left(D^{-}\right)$.

Tabel 8 Solusi Ideal Positif dan Negatif

\begin{tabular}{ccccc}
\hline \multicolumn{2}{c}{ Jarak Alternatif terhadap Solusi Ideal } & \multicolumn{3}{c}{ Jarak Alternatif terhadap Solusi Ideal } \\
Positif & Nilai & Kogatif & Nilai \\
\hline$D_{1}^{+}$ & 13,6197 & $D_{1}^{-}$ & 5,2680 \\
$D_{2}^{+}$ & 1,3188 & $D_{2}^{-}$ & 16,7417 \\
$D_{3}^{+}$ & 14,1361 & $D_{3}^{-}$ & 9,1346
\end{tabular}

Tabel 8 diperoleh dengan memindahkan dan mengatur MAX dan nilai MIN. Langkah terakhir yakni mencari nilai preferensi tiap alternatif yang diilustrasikan pada Tabel 9.

Tabel 9 Nilai preferensi

\begin{tabular}{ccc}
\hline Kode & Nilai & Ranking \\
\hline$V_{1}$ & 0,278910471 & $\mathbf{3}$ \\
$V_{2}$ & 0,926980764 & $\mathbf{1}$ \\
$V_{m}$ & 0.392538212 & $\mathbf{2}$
\end{tabular}

Nilai preferensi diperoleh dari jumlah seluruh nilai solusi ideal dibagi dengan 
ILKOM Jurnal Ilmiah Volume 8 Nomor 2 (Agustus 2016)

Etotal nilai $M A X+$ total nilai Min

\subsection{Perbandingan SAW dengan TOPSIS}

Untuk mengetahui metode yang baik, maka dilakukan perubahan pembobotan. Yang diilustrasikan pada Tabel 10 berikut:

Tabel 10 Pemberian Bobot

\begin{tabular}{cccc}
\hline Kode Bobot & $\begin{array}{c}\text { Nilai Bobot } \\
\text { Lama } \mathbf{~}\end{array}$ & $\begin{array}{c}\text { Nilai Bobot Baru } \\
\mathbf{2}\end{array}$ & $\begin{array}{c}\text { Nilai Bobot Baru } \\
\mathbf{3}\end{array}$ \\
\hline$W_{1}$ & 20 & 30 & 15 \\
$W_{2}$ & 30 & 15 & 20 \\
$W_{3}$ & 35 & 35 & 30 \\
$W_{4}$ & 15 & 20 & 35 \\
\hline
\end{tabular}

Langkah selanjutnya dilakukan proses perangkingan. Sehingga diperoleh nilai yang sama pada tiap-tiap pembobotan seperti ilustrasi Tabel 11 berikut:

Tabel 11 Perangkingan metode SAW dan TOPSIS

\begin{tabular}{ccc}
\hline Kode Bobot & Ranking SAW & Ranking TOPSIS \\
\hline$A_{1}$ & 3 & 3 \\
$A_{2}$ & 1 & 1 \\
$A_{n}$ & 2 & 2
\end{tabular}

Tabel 11 menunjukkan ada kesamaan penggunaan metode SAW dan TOPSIS untuk pengambilan suatu keputusan.

\section{Kesimpulan dan saran}

Dari beberapa proses pengujian, maka disimpulkan:

- Alternatif yang mengantarkan perusahaan meningkatkan omzet adalah dengan memilih lokasi Antang untuk mengembangkan usahanya.

- Berdasarkan pengamatan menggunakan model SAW dan TOPSIS dengan melakukan pergantian bobot maka kami melihat bahwa kedua model tersebut memiliki kesamaan dalam proses pemecahan masalah.

Adapun saran penelitian ini adalah:

- Dapat dijadikan acuan dan pedoman untuk memilih lokasi yang strategi dalam pengembangan usaha

- Menggunakan metode pengambilan keputusan yang lain dan membandingkannya dengan metode SAW dan TOPSIS

\section{Daftar Pustaka}

[1] R. H. Bonczek, C. W. Holsapple, and A. B. Whinston, "Future Directions For Developing Decision Support Systems," Decis. Sci., vol. 11, no. 4, pp. 616-631, 1980.

[2] E. Turban and J. Aronson, Decision Support Systems and Intelligent Systems. 2005.

[3] D. L. Kurniasih, "Sistem Pendukung Keputusan Pemilihan Laptop Dengan Metode Topsis," Pelita Inform. Budi Darma, vol. III, no. April, pp. 6-13, 2013.

[4] A. N. Pramudhita, H. Suyono, and E. Yudaningtyas, "Penggunaan Algoritma Multi Criteria Decision Making dengan Metode Topsis dalam Penempatan Karyawan,” vol. 9, no. 1, pp. 91-94, 2015.

[5] V. Fuspita, A. Vatresia, and D. Andreswari, "Sistem Pendukung Keputusan Pemilihan Restoran Di Kota Bengkulu Dengan Metode Simple Additive Weighting (Saw) Berbasis Sistem Operasi Android," J. Rekursif, vol. 2, no. 1, pp. 45-52, 2014. 